\title{
DERMATOSCOPY IN DIAGNOSING MACULOPAPULAR CUTANEOUS MASTOCYTOSIS
}

\section{AUTHORS}

Popadić Mirjana ${ }^{1,2}$

${ }^{1}$ Department of Dermatovenereology, Medical University of Belgrade

${ }^{2}$ Clinic of Dermatovenereology, Clinical Centre of Serbia, Belgrade, Serbia

\section{CORRESPONDENT}

MIRJANA POPADIĆ

Medical University of Belgrade, Clinic of Dermatovenereology, Clinical Centre of Serbia, Serbia

$\square$ mirjana.popadic@kcs.ac.rs

\section{SUMMARY}

The diagnosis of cutaneous mastocytosis is based on the clinical finding of the pigmented macules or papules, positive Darier's sign and a dermal infiltrate composed of mast cells that can be better visualized by the use of special stains (Giemsa or Toluidine blue). Clinical, dermatoscopic and histopathological presentations of new appearing pigmented lesions in a female patient were presented. Dermatoscopic findings of pigment network-like structure combined with parallel pigmented lines and central reddish background in a adult patient with new appearing pigmented lesions should led us to searching for cutaneous mastocytosis.

Key words: cutaneous mastocytosis, urticaria pigmentosa, dermatoscopy, dermoscopy, pigment network

\section{INTRODUCTION}

Mastocytosis is a rare disease characterized by proliferation and accumulation of mast cells in various organs (bone marrow, skeletal system, gastrointestinal tract, spleen, lymph nodes and liver), most commonly in the skin.[1] It is classified as cutaneous or systemic mastocytosis. Cutaneous mastocytosis (CM) is further classified into the five groups by Hartmann and Henz (Table 1). [2]

In recent years, dermatoscopy has emerged as a simple and useful tool for the diagnosis of melanocytic and nonmelanocytic skin lesions, providing rapid and easy evaluation of the colors and microstructure of the epidermis, the dermoepidermal junction, and the papillary dermis, not visible to the naked eye. [3,4] Several diagnostic algorithms based on the use of dermatoscopy have been developed for melanocytic and nonmelanocytic skin lesions. One of the main criteria for the diagnose of melanocytic lesions is the presence of the brown reticular lines (pigmented network). However, this dermatoscopic structure is also seen in numerous nonmelanocytic lesions such as dermatofibroma, solar lentigo, seborrheic keratosis, accessory nipple, Kaposi's sarcoma and even in the normal skin. [5-7] Skin lesions of mastocytosis represent one more nonmelanocytic lesion that may exhibit a pigment network. $[1,3,4,8]$

\section{CASE REPORT}

A 43-year-old healthy woman with Fitzpatrick skin photo type II presented due to increase in the number of "moles", over the last 6 years. Clinically, lesions were indistinguishable from melanocytic nevi, presented as numerous small brown macules and maculopapules scattered all over the trunk (Fig. 1) and extremities. Although, the lesions were not irregular in shape and pigmentation, appearance of new moles in middle aged person required dermatoscopic examination.

Under the dermatoscope, the light brown lines were seen, drawing up a fine, irregular pigment network with accentuation of pigmentation along natural folds of the skin (Fig. 1.1). The background color was reddish in the centre, surrounded by light brown color with regular fading out in color intensity towards periphery of the lesions.

A biopsy specimen one of pigmented lesions marked as Fig.1.1 revealed slight epidermal orthokeratotic hyperkeratosis, moderate acanthosis, and increased number of melanocytes in the basal layer with no other changes in the epidermis (Figure 2). The dermis was edematous and consisted of moderate infiltration of lymphocytes, and eosinophils around the blood vessels with groups of mast cells (HE, and toluidine blue stained). The histologic diagnosis of cutaneous mastocytosis was established.

\section{DISCUSION}

Maculopapular cutaneous mastocytosis, also known as urticaria pigmentosa is the most common form of cutaneous mastocytosis. [4] Although it can affect adults, usually it begins in childhood. Urticaria pigmentosa in adults is more likely to progress to systemic disease and its severity is related to the age of onset and to the size of cutaneous involvement. [1,9] Therefore, early diagnosis of CM is preferred. 


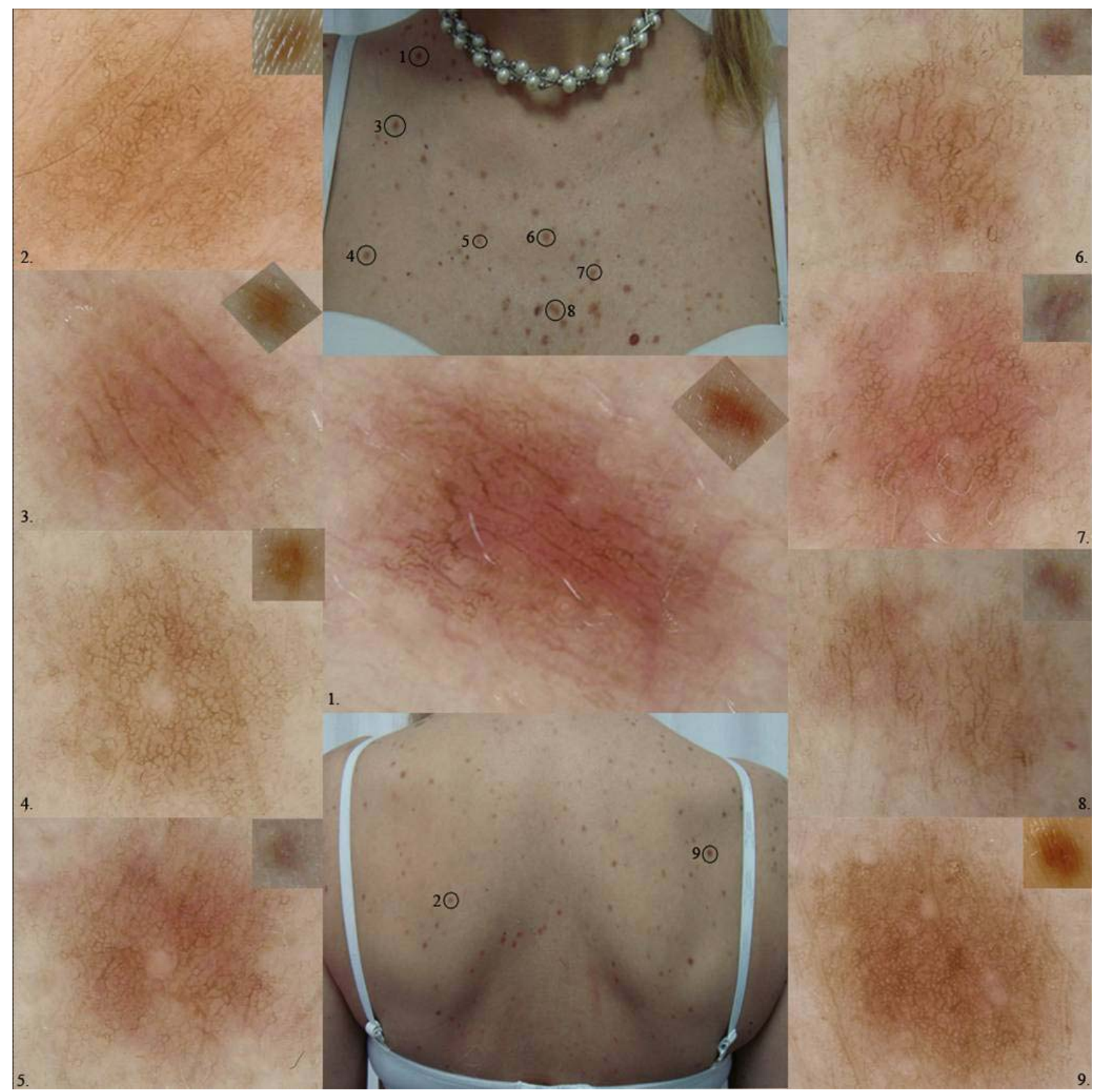

Figure 1.1-9. Mastocytosis and melanocytic nevi, clinical presentation: Numerous light brown macules and maculo-papules scattered all over the upper trunk; Figure 1.1. Dermatoscopy: Discrete irregular pigment network with linear accentuation of pigmentation along the skin folds and reddish centre in the background

(DermLite Photo dermatoscope, 3Gen LLC, Dana Point, CA x10)

Although, presented patient had onset of cutaneous mastocytosis in her middle age, she was healthy, with no systemic involvement and with negative Darier's sign. Because of the lacking simptoms associated with $\mathrm{CM}$, making a correct diagnosis in this patient is challenging. However, the dermatoscopic analysis can be useful to distinguish $\mathrm{CM}$ from epidermal melanocytic nevi. Several studies reported dermatoscopic findings of CM. All of them agreed that maculopapular CM, is dermatoscopically presented with brown reticular lines in combination with reddish to brown blot. $[1,3,4,8]$ Dermatoscopic analysis of pigmented lesions in the presented patient, revealed irregular reticular lines with no typical regular holes as they can be usually seen in epidermal melanocytic nevi. Therefore, the term pigment networklike structure is more suitable to use in the presented case than pigment network. In addition, pigmentation is accentuated in the normal skin folds as longer, brown parallel lines in combination with central reddish background, which can not be seen in epidermal melanocytic nevi. These dermatoscopic features may help to differentiate $C M$ from epidermal melanocytic nevi.

On the basis of these observations, two of nine (Figure 1.1 (HP verified) and 1.3) presented pigmented lesions clearly fulfill the described features and distinguishes themselves from the other lesions. 


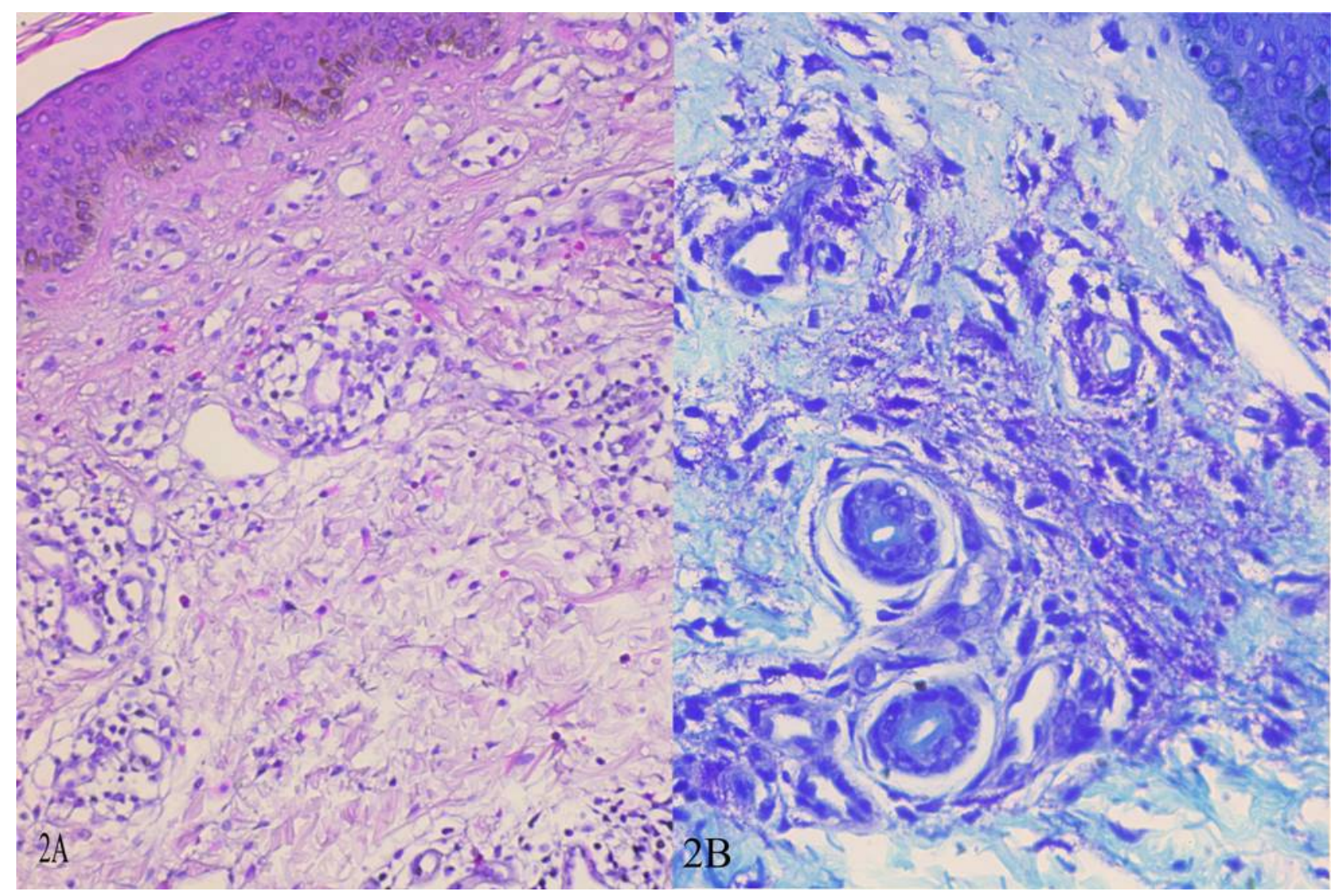

Figure 2A. Mastocytosis, histopathology: Almost normal epidermis with increased number of melanocytes in the basal layer, and moderate dermal cellular infiltrate consisting of lymphocytes, eosinophils and groups of mast cells (HEx200); 2B. Magnified view of intact and degranulated mast cells (toluidine blue, x400).

\section{CONCLUSION}

In conclusion, dermatoscopy, can be of great help in recognizing $C M$. This article should increase awareness of clinicians to cutaneous mastocytosis that can resemble melanocytic nevi, not only clinically but also dermatoscopically. A progressive increase in the number of pigmented lesions in a adult patient should lead us to perform a dermatoscopy and subsequently a biopsy to search for mastocytosis.

\section{REFERENCES}

1. Miller MD, Nery NS, Gripp AC, Maceira JP, Nascimento GM. Dermatoscopic findings of urticaria pigmentosa. An Bras Dermatol. 2013;88(6):986-988.

2. Hartmann K, Henz BM. Classification of cutaneous mastocytosis: a modified consensus proposal. Leuk Res. 2002;26(5):483-484.

3. Akay BN, Kittler H, Sanli H, Harmankaya K, Anadolu R. Dermatoscopic findings of cutaneous mastocytosis. Dermatology. 2009;218(3):226-230.

4. Vano-Galvan S1, Alvarez-Twose I, De las Heras E, Morgado JM, Matito A, Sánchez-Muñoz L, Plana MN, Jaén P, Orfao A, Escribano L. Dermoscopic features of skin lesions in patients with mastocytosis. Arch Dermatol. 2011;147(8):932-940.

5. Argenziano G, Soyer HP, Chimenti S, Talamini R, Corona R, Sera F, et al. Dermoscopy of pigmented skin lesions: results of a consensus meeting via the internet. J Am Acad Dermatol. 2003;48:679-693. 
6. Scope A, Marghoob AA, Chen CS, Lieb JA, Weinstock MA, Halpern AC, et al. Dermoscopic patterns and subclinical melanocytic nests in normalappearing skin. Br J Dermatol. 2009;160:1318-1321.

7. De Giorgi V, Massi D, Stante M, Carli P. False "melanocytic" parameters shown by pigmented seborrheic keratoses: a finding which is not uncommon in dermoscopy. Dermatol Surg. 2002;28:776-779.

8. Gutiérrez-González E, Ginarte M, Toribio J. Cutaneous mastocytosis with systemic involvement mimicking clinical and dermatoscopically multiple melanocytic nevi. Dermatol Online J. 2011;17(11):15.

9. Wolff K, Komar M, Petzelbauer P. Clinical and histopathological aspects of cutaneous mastocytosis. Leuk Res. 2001;25:519-528.

\section{SRPSKI}

\section{DERMATOSKOPIJA U DIJAGNOSTICI MAKULOPAPULARNE KUTANE MASTOCITOZE}

Popadić Mirjana ${ }^{1,2}$

${ }^{1}$ Katedra za dermatovenerologiju, Medicinski fakultet Univerziteta u Beogradu

${ }^{2}$ Klinika za dermatovenerologiju Kliničkog centra Srbije, Beograd, Srbija

\section{SAŽETAK}

Dijagnoza kutane mastocitoze bazirana je na kliničkom nalazu pigmentnih makula ili papula, pozitivnom Darier znaku i nalazu dermalnog infiltrata sačinjenog od mast ćelija, koje se bolje vizualizuju primenom specijalnog bojenja (Giemsa ili toluidin plavo). Prikazane su kliničke, dermatoskopske i histopatološke karakteristike novih pigmentnih lezija kod pacijenta ženskog pola. Dermatoskopskim pregledom novih lezija odraslog pacijenta, nalaz struktura nalik pigmentnoj mreži u kombinaciji sa paralelnim pigmentnim linijama i centralnom crvenkastom pozadinom, upućuje na ispitivanje u pravcu kutane mastocitoze.

Ključne reči: kutana mastocitoza, urticaria pigmentosa, dermatoskopija, dermoskopija, pigmenta mreža 